\title{
O POVO APURINÃ CONTRA O PODER COERCITIVO
}

\author{
Rogério Sávio Link ${ }^{1}$
}

\section{Resumo}

Este artigo discute o controle social do povo Apurinã em relação ao poder coercitivo. O objetivo é analisar como a sociedade apurinã estava e ainda está estruturada para delimitar o poder das lideranças políticas e religiosas evitando, assim, o aparecimento do poder coercitivo e da sociedade dividida em classes sociais. Para alcançar esse objetivo, a análise apoia-se principalmente nos trabalhos de Pierre Clastres, Hélène Clastres e Marcel Gauchet. Pierre Clastres chega à conclusão de que todo poder nas sociedades indígenas emana da comunidade. As lideranças seriam desprovidas de poder coercitivo e, dessa forma, as sociedades indígenas seriam "sociedades contra o Estado", a forma mais acabada de poder coercitivo que institui o aparecimento das classes e do trabalho alienado. A partir de dados históricos e etnográficos, este artigo dialoga com a tese de Clastres buscando apresentar o ponto de vista dos Apurinã visibilizado em sua história e em suas narrativas míticas. Mas, diferente de Clastres, para quem o poder coercitivo parece provir mais substancialmente do grupo dos guerreiros, para os Apurinã, ele parece provir perigosamente da religião. As principais fontes históricas e etnográficas aqui utilizadas são de duas ordens: extratos de cartas e relatórios produzidos por missionários da South American Missionary Society entre as décadas de 1870 e 1880; e observações de campos decorrentes de minha convivência com os Apurinã do Médio Purus.

Palavras-chave: Apurinã; poder coercitivo; poder político; xamanismo; Amazônia.

\begin{abstract}
This article discusses the social control of Apurinã people regards to the coercive power. The objective is to analyze how Apurinã society was and still is structured to delimit the power of the political and religious leaderships, thus avoiding the emergence of coercive power and of a society divided into social classes. To achieve that objective, the analysis is mainly based on the work of Pierre Clastres, Hélène Clastres and Marcel Gauchet. Pierre Clastres comes to the conclusion that all power in indigenous societies emanates from the community. The leaderships would be deprived of coercive power and thus indigenous societies would be "societies against State", the most finished form of coercive power that institutes the emergence of classes and alienated labor. From historical and ethnographic data, this article dialogues with the thesis of Clastres seeking to present the point of view of Apurinã visible in its history and in its mythical narratives. But unlike Clastres, for whom coercive power seems to come more substantially from the warrior class, to the Apurinã, it seems to come dangerously from religion. The main historical and ethnographic sources used here are of two orders: extracts from letters and reports produced by missionaries of the South American Missionary Society between the 1870s and 1880s; and field observations resulting from my convivialite with the Apurinã of the Middle Purus.
\end{abstract}

Keywords: Apurinã; coercive power; political power; shamanism; Amazon.

1 Professor Adjunto do Departamento de História da Universidade Federal de Rondônia (UNIR). Licenciado em História pela Universidade Federal do Rio Grande do Sul (UFRGS). Doutor em Teologia pela Faculdade EST (2008). Doutor em História pela UFRGS (2016). Pós-doutor em História Indígena pela Universidade Federal da Grande Dourados (UFGD). O presente trabalho foi realizado com apoio do CNPq, Conselho Nacional de Desenvolvimento Científico e Tecnológico - Brasil. E-mail: rogerio.link@unir.br 


\section{Introdução}

Este artigo é parte dos resultados de um projeto de pesquisa de doutoramento em História Indígena defendido em 2016 na UFRGS. Ele discute o controle social do povo Apurinã em relação ao poder coercitivo. Meu objetivo aqui é abordar como a sociedade apurinã estava e ainda está estruturada para delimitar o poder das lideranças políticas e religiosas. Para alcançar esse objetivo, minha análise apoia-se no trabalho de Pierre Clastres (2012 [1974]; 2014 [1978]) que, como também observou Carlos Fausto (1999: 260), afirma a primazia do político sobre o econômico. A partir de dados históricos e etnográficos, dialogo com a tese de Clastres buscando apresentar o ponto de vista dos Apurinã visibilizado em sua história e em suas narrativas míticas. Mas, diferente de Clastres, para quem o poder coercitivo parece provir mais substancialmente do grupo dos guerreiros, para os Apurinã, ele parece provir perigosamente da religião.

Assim, a análise do conteúdo histórico e etnográfico é feita a partir do entrecruzamento do poder político com o poder religioso. Os trabalhos de Hélène Castres (1978), afirmando a descontinuidade entre o profetismo tupi e o exercício do poder político, e de Marcel Gauchet (1980), afirmando a ruptura entre a sociedade igualitária e a sociedade de classes como proveniente da religião, são também tomados para discutir o problema. Para Hélène Castres, a confluência dos fenômenos religiosos e políticos em uma mesma liderança é exceção proveniente das vicissitudes do pós-contato que enfraqueceram o controle social sobre as lideranças e possibilitou o surgimento do poder coercitivo. Já Gauchet vai dizer que, depositando o sentido de sua existência fora de si mesma (na religião), a sociedade operaria a primeira ruptura necessária para a segunda ruptura quando as pessoas que representariam as divindades passaram a exercer poder sobre os demais em nome dessas divindades.

Um trabalho semelhante ao meu foi feito por Renato Sztutman (2005) em sua tese de doutoramente intitulada "O profeta e o principal". A partir dos trabalhos de Pierre Clastres e de Hélène Clastres (1978), esse autor trabalha com uma revisão bibliográfica exaustiva a respeito dos Tupi. Já o meu trabalho se diferencia por ser sobre um grupo Aruak e por utilizar dados históricos e etnográficos coletados em campo, mas o princípio da crítica é a mesma, qual seja, trabalhar com a emergência do poder coercitivo numa sociedade indígena.

As principais fontes históricas e etnográficas aqui utilizadas são de duas ordens: 1) extratos de cartas e relatórios produzidos por uma missão anglicana - South American 
Missionary Society (SAMS) que manteve missionários e missionárias no Rio Purus entre as décadas de 1870 e 1880 - e publicados na revista South American Missionary Magazine (SAMM); 2) e observações de campos decorrentes de minha convivência com os Apurinã do Médio Purus entre agosto de 2008 a agosto de 2010 como assessor de um projeto de revitalização linguística e cultural entre os Apurinã mantido pelo Conselho de Missão entre Povos Indígenas (COMIN) e observações feitas entre janeiro e fevereiro de 2013 durante uma pesquisa de campo.

\section{Controlando políticos e guerreiros}

\section{A fragmentação do poder político como estratégia de controle social}

A primeira coisa que podemos tomar como uma afirmação axiológica é que, antes do contato intensivo, as lideranças apurinã (kiumãnety) eram desprovidas de poder coercitivo e que todos os Apurinã se consideravam e se consideram eles mesmos como chefes. Ou como afirmou o Coronel Antonio Rodrigues Pereira Labre, colonizador do Purus que, em 1871, estabeleceu sua colônia no estuário do Rio Ituxi, atual cidade de Lábrea: "não há distinção e nem privilégio algum, nem tampouco para o chefe e sua família, que nivelada com as outras, trabalha e vive do mesmo modo, não tendo servos ou criados" (LABRE, 1872: 16). Isso não quer dizer que os Apurinã desconheciam o poder exercido coercitivamente; ao contrário, como tentarei argumentar, os chefes apurinã não possuíam poder de mando justamente porque a sociedade apurinã se colocava e se coloca contrária à existência de tal poder. Meu objetivo aqui é justamente abordar como a sociedade apurinã estava e ainda está estruturada para delimitar o poder das lideranças políticas. Para Pierre Clastres $(2012: 211,219,231$; 2014: 142) todo poder nas sociedades indígenas emana da comunidade. As lideranças seriam desprovidas de poder coercitivo e, dessa forma, as sociedades indígenas seriam "sociedades contra o Estado", a forma mais acabada de poder coercitivo que institui o aparecimento das classes e do trabalho alienado. A argumentação de Clastres é que as sociedades indígenas não estruturadas em classes teriam sido na realidade eficazes na sua "luta" para impedir que relações sociais de exploração emergissem. Isso porque o poder não está na figura de um chefe supremo. Ao contrário, "o chefe está a serviço da sociedade, é a sociedade em si mesma - verdadeiro lugar do poder - que exerce como tal sua autoridade sobre o chefe" 
(CLASTRES, 2012: 221). Assim, o igualitarismo seria uma prevenção contra o Estado (SCOTT, 2009: 274ss).

No final do século XIX, Paul Ehrenreich (1891: 65) - antropólogo alemão que descreveu os primeiros anos de contato - também observou esse igualitarismo entre os Apurinã. Para esse autor, a figura do chefe era totalmente desprovida de poder de mando e, quando perguntados por seu chefe, os Apurinã sempre respondiam que entre eles todos eram chefes. É interessante notar que mais de um século depois, obtive várias vezes a mesma explicação de diferentes interlocutores. Marco Antônio Lazarin (1981: 79) e Juliana Schiel (2004: 85) também vão identificar a mesma problemática; o que é sinal de uma estrutura de longa duração. Nesse sentido, Ehrenreich também vai dizer que os Apurinã chamavam seu chefe de enẽkakary. Infelizmente não consegui verificar o uso desta palavra na atualidade. Ao invés dela, obtive a palavra kiumãny (liderança) que é também utilizada para designar os sábios ancestrais. Há que se dizer, no entanto, que essa palavra somente surgiu depois de um longo processo de consulta e que, portanto, ela pode estar muito longe daquilo que a sociedade não-indígena entende como chefe. $\mathrm{Na}$ atualidade, ao falar da figura do chefe, os Apurinã utilizam palavras provenientes do contexto regional como cacique e tuxaua. O próprio missionário Jacob Evert Resyek Polak, que atuou entre 1873 e 1881 com os Apurinã, não registrou em sua gramáticadicionário (1894) nenhum termo que correspondesse a uma figura de chefe ou liderança. Em novembro de 1875, o missionário Robert Stewart Clough afirma que "cada comunidade é governada por um tuxaua ou chefe [tuchaua or chief], mas outro principal [head man] possui uma autoridade praticamente igual aquela de seu superior nominal" (SAMM, 1876: 112). A questão parece ser assim bastante evidente: não existia uma tal figura separada da comunidade que merecesse receber um atributo que a distinguisse em graus dos demais. A sociedade apurinã não estava dividida entre aqueles que mandavam e aqueles que obedeciam. Portanto, entre os Apurinã, em vez de chefe, é melhor falar em liderança. E a figura da liderança somente é reconhecida como tal pela sua capacidade de servir à coletividade.

O serviço que as lideranças prestam à comunidade, segundo Clastres (2012: 48, 55), depende das qualidades exigidas pela comunidade que são: ser bom orador para representar a comunidade, ser generoso trabalhando mais do que os outros e redistribuindo os bens e ser um apaziguador de conflitos. Em troca recebe da comunidade o privilégio da poliginia. Em relação aos Apurinã, Clastres (2012: 55) vai afirmar que o 
chefe será aquele que se destaca como um dos melhores caçadores. No entanto, essa parece ser uma informação superficial e equivocada, ou seja, sem observação etnográfica.

O fato de ser bom caçador, não faz de ninguém uma liderança política; seus atributos como bom caçador são reconhecidos somente no momento da caça. Para ser liderança política, os atributos exigidos são outros. No caso dos Apurinã, a liderança parece ser aquela que melhor lida com as fronteiras culturais. Portanto, a liderança apurinã é alguém que se destaca na capacidade diplomática, geralmente evidenciada pelo domínio da língua do estrangeiro. No contexto pós-contato, a liderança geralmente era alguém que falava bem o português. Talvez por isso tenhamos muitos relatos de que os Apurinã entregavam sistematicamente suas crianças para os não-indígenas, para os ĩparãnyry ${ }^{2}$. Parece que a "doação de crianças" instituía um rito de passagem que visava o domínio do mundo do karywa. Pelo menos essa tem sido minha argumentação (LINK, 2016: 103123). Disso podemos inferir que essa situação também seria verídica para o período anterior ao contato com os ĩparãnyry, o que é evidenciado, sobretudo, nos relatos que afirmavam a existência de alguns Apurinã vivendo entre outros grupos indígenas e desempenhando um papel de liderança justamente por dominar uma habilidade linguística necessária (LINK, 2016: 184, 240). Com essa estratégia, portanto, os Apurinã parecem dar continuidade ao processo de formar lideranças; e, quanto mais lideranças - mais fragmentação do poder político -, menos chance de serem coagidos e explorados. A educação para que todos sejam chefes fragmenta e impede que um grupo domine exclusivamente o campo da atuação política.

Assim, a capacidade diplomática parece ser um ponto central para que um Apurinã possa ser reconhecido como uma liderança. Esse atributo está ligado, obviamente com a capacidade oratória. E esse talento oratório é exigido tanto para representar a comunidade para fora do grupo quanto também para representar os anseios internos da própria comunidade. Mas quando o discurso da liderança dirigir-se à comunidade, geralmente esta não presta a menor atenção. Com essa indiferença, a comunidade parece lembrar seu chefe que ele não detém nenhum poder de mando (CLASTRES, 2012: 50s). De

\footnotetext{
${ }^{2}$ Os Apurinã possuem dois termos para se referirem aos não-indígenas: karywa e ĩparãnyry. O primeiro é um empréstimo da Língua Geral Amazônica (no português atual cariú) e é compartilhado entre vários povos indígenas da região amazônica. Provavelmente, os primeiros exploradores falantes da língua geral, ao entrarem em contato com os indígenas, utilizavam esse termo para se referirem a eles mesmos e o termo foi sendo transmitido de povo para povo. O segundo etnônimo, por sua vez, provém da própria língua apurinã e denota a conjuntura do momento histórico a partir do qual os Apurinã perceberam a chegada desses forasteiros que adentravam seu território e pode ser traduzido como "aqueles que chegam com a época das chuvas".
} 
semelhante forma, atualmente, da liderança apurinã, exige-se que pronuncie discursos dos quais a comunidade geralmente permanece indiferente. É também obrigação das lideranças organizarem festas e reuniões políticas das quais uma grande parte da comunidade não contribui ou nem mesmo participa. As lideranças, notadamente, reclamam dessa situação, mas a comunidade parece impassível frente a essas admoestações. As lideranças são assim constantemente lembradas que elas não detêm nenhum poder de fato. Mesmo assim, as festas organizadas pelas lideranças têm como um de seus fundamentos a manutenção do prestígio e ou a tentativa de construção de hierarquias sociais. Elas são organizadas geralmente para celebrar a morte de lideranças. Ao celebrar e reviver os feitos, os vivos estão agenciando o poder simbólico do morto em benefício próprio. É a consolidação do prestígio familiar que está em jogo. E a realização de festas traduz-se, obviamente, em poder político. Dessa forma, embora as hierarquias sociais possam ser menos presentes entre os Apurinã e entre os demais Aruak do Sul da Amazônia do que em relação aos seus vizinhos do Norte (HILL; SANTOS-GRANERO, 2002: 19), certamente ela também é uma característica observável.

Embora cada Apurinã seja formado para exercer a liderança, essa tarefa de fato parece recair preferencialmente sobre alguns indivíduos. Geralmente é chefe quem tem uma rede familiar maior. Se a capacidade da rede familiar tende a delimitar o reconhecimento de uma liderança, isso implica que geração após geração as lideranças tendem a provir das mesmas famílias, pois essas são as famílias maiores. Assim como entre os demais Aruak (SANTOS-GRANERO, 2002: 44s), a linhagem parece, pois, representar um importante componente para que um Apurinã seja reconhecido como liderança. A rede familiar e a linhagem são, assim, o suporte das lideranças. E são suporte, sobretudo, porque ajudam as lideranças no serviço à comunidade.

Portanto, uma rede familiar ampliada auxilia a liderança na tarefa de servir à comunidade. Tradicionalmente, como também descreveu Clastres (2012: 60), numa comunidade indígena, a liderança é quem trabalha mais arduamente. Geralmente é ela quem tem o maior roçado, o qual fica a disposição da comunidade, pois a liderança é quem tem a obrigação da generosidade. $\mathrm{O}$ acúmulo de bens desproporcionais não é algo aceito pela comunidade. Dessa forma, a obrigação de ser generoso impede que a liderança consiga obter vantagens de seu posto acumulando bens e distinguindo-se dos demais. Uma liderança que tenta transformar seu poder em vantagem é simplesmente abandonada pela comunidade (CLASTRES, 2012: 171). Assim, o prestígio de um chefe - ou seu capital simbólico (BOURDIEU, 1996: 170) - é medido pela sua capacidade de 
generosidade, sua capacidade de doação para e pela comunidade. Quanto mais uma liderança doa, mais prestígio ela tem. No período pós-contato, a capacidade de chefia passou a ser medida também pelo acesso que as lideranças propiciavam aos bens manufaturados. Por exemplo, em 1881 o missionário William Thwaites Duke, escrevendo desde o Rio Mamoriá quando estava em uma viagem ao Rio Seruini, faz a seguinte observação:

No meu retorno desta viagem [ao Seruini], eu espero visitar novamente o Sepatini, porque eu ouvi do Senhor Barbosa, que vive perto daqui [da boca do Rio Mamoriá] e que nos acompanhou em nossa visita aos índios, que um chefe de um ponto mais alto do Sepatini esteve em sua casa e reclamou que o pequeno vapor não tenha ido até a sua aldeia. Ele disse: "os outros dois chefes são bons [chefes que Duke teria visitado]; mas eu não sou bom, pois você não veio me ver com o pequeno vapor". Ele também disse que lá ele tem um grande número de crianças. (SAMM, 1881: 187, tradução própria)

Se o lamento da liderança foi registrado corretamente pelo missionário, podemos então concluir que o chefe ansiava para que os missionários fossem até sua aldeia tanto quanto os missionários ansiavam para ir. O relato deixa entrever que essa liderança estaria preocupada com o fato dos missionários terem visitado outras aldeias nas imediações e negligenciado a sua. Situação que o colocava em uma posição de menor prestígio perante os chefes das outras aldeias e perante a sua própria aldeia. Podemos inferir que sua comunidade o admoestava para que ele também conseguisse que os ĩparãnyry, portadores de bens desejáveis, viessem até eles. Talvez por isso, esse chefe tenha empreendido uma viagem até o Purus para tentar contatar os missionários para que também fossem visitálos. E, como alguém que sabe o que os missionários estão procurando, acrescenta que a aldeia estaria cheia de crianças.

Em troca dos seus serviços prestados, as comunidades indígenas parecem admitir que as lideranças tomem mais de uma esposa. Como as lideranças precisam ter uma base familiar ampliada para servir à comunidade, essa situação é amplamente aceita. Daí a observação etnográfica recorrente de que a poliginia seria prerrogativa dos chefes em muitas comunidades. Entre os Apurinã, a poliginia também parece ter sido privilégio das lideranças. Em mais de uma ocasião, os missionários observaram que as lideranças tinham mais de uma esposa (SAMM, 1876: 112, 116).

\section{$O$ arquétipo da vingança como antídoto ao poder coercitivo}

Até aqui descrevi a natureza do poder político. Outra questão que chama a atenção nas fontes históricas é o excesso de violência interna entre os Apurinã. Como também 
observou Juliana Schiel (SCHIEL, 2004: 266s), a violência entre os Apurinã parece ter uma incidência significativa e é narrada como uma condição decorrente da "terra do meio"3. Sem dúvida a participação na sociedade nacional levou os Apurinã a potencializarem o conflito interno. Assim, o contato com a sociedade nacional acentuou conflitos e desestruturou a sociedade apurinã; mas, como argumento, essa situação de conflito também é decorrente da própria cultura apurinã. A chegada do iparãnyry trouxe a divisão social em termos de exploração e muitos Apurinã, não aceitando essa situação, se insurgiram. Daí a escalada crescente de violência interna descrita pelos missionários, exploradores e colonizadores.

No entanto, essa situação de violência não pode ser creditada somente ao contexto pós-contato. Ela certamente tem uma causa mais profunda vinculada à estrutura cultural apurinã. A análise das fontes mais antigas já aponta a incidência de conflitos internos, que em decorrência do contexto de colonização fora descrito por vezes como propensão para a guerra. Meu argumento aqui é que, embora os Apurinã pudessem ser descritos como guerreiros, os conflitos esporádicos e localizados não corroboravam com a interpretação de um estado de beligerância (LINK, 2016: 203, 205, 218-220). No entanto, se nunca fora registrado um estado efetivo de guerra - uma "sociedade de guerreiros" como diria Clastres (2014: 279) - que opunha o conjunto da sociedade Apurinã aos iparãnyry ou a outros grupos indígenas, o mesmo não se pode dizer dos conflitos internos. $\mathrm{Na}$ realidade, como a análise das fontes sugere, os conflitos registrados sempre foram internos, ou seja, envolviam facções internas e ou estrangeiros que estavam sendo “consanguinizados”. Os Apurinã parecem viver, então, um estado de guerra em potencial. Clastres (2014: 279) chama isso de "estado de guerra permanente". Os estudos antropológicos mais recentes, vão vincular esses conflitos à instituição da vingança que parece fazer parte da estrutura social apurinã e que seria, em última instância, responsável pela escalada de violência no contexto pós-contato. Na cosmologia apurinã, a vingança, assim, é descrita como um legado do começo do mundo quando "os filhos de Yakonero [Yakuneru] vingam a morte de sua mãe, matando seus 'avós"' (SCHIEL, 2004: 227). Os filhos de Yakuneru seriam Erutã, Uxurũku, Ekipaã e Tsura e se vingariam de Katsamãũteru pela morte de sua mãe (SCHIEL, 2004: 227). Tsura é o protagonista maior e é quem sempre é lembrado como aquele que instituiu a obrigatoriedade da vingança.

\footnotetext{
${ }^{3}$ Cosmologicamente, os Apurinã consideram-se como um povo que vive na terra do meio entre duas terras de perfeição (Kairiku e Iputuxity). Eles teriam empreendido uma migração originária e permaneceram na terra do meio (LINK, 2016: 257).
} 
Não estou interessado aqui em analisar exaustivamente a estrutura do mito. Minha intenção é somente pontuar que a vingança, ao contrário do que Florestan Fernandes (2006: 85) vai dizer sobre os Tupinambá, parece ser o motor de toda a violência registrada entre os Apurinã; e ela está presente em suas narrativas míticas. Fernandes, ao analisar a função da guerra na sociedade tupinambá, dá primazia para o econômico. Por causa disso, mesmo evidenciando que as fontes históricas (cronistas) apontam para a vingança como o motor principal das guerras dos Tupinambá, Fernandes $(2006: 66,85)$ vai afirmar que elas eram geradas pelas disputas por território. Inspirado em Clastres, minha intenção é antes vincular a vingança - entendida aqui como a potencialidade para o conflito - com a estrutura social igualitária da sociedade apurinã. Minha tese é que a vingança é justamente o antídoto da comunidade contra a emergência de um poder coercitivo.

Juliana Schiel (2004: 79) vincula a vingança à questão da guerra, de forma que ela acaba assumindo o discurso dos Apurinã como guerreiros. No entanto, a partir de sua etnografia ela também percebe que a realidade empírica não sustenta a ideologia de que os Apurinã seriam dados à guerra. Sua saída então foi descrever uma transição da guerra para a vingança. "Hoje, então, a guerra não é mais uma instituição, mas a vingança e os conflitos são presentes e constroem a maneira como os Apurinã pensam e vivem. Os conflitos, muitos com mortes, são inúmeros e a sua memória traz consigo novos conflitos potenciais" (SCHIEL, 2004: 80). Assim Schiel tenta sustentar que o contexto pós-contato teria impossibilitado a guerra e deixado em seu lugar somente a vingança. Se a vingança originária instituía a guerra, no contexto pós-contato ela parecia instituir apenas a violência. Para ela, as instituições indigenistas (CIMI, OPAN e UNI) teriam contribuído para que as famílias separadas pelo receio de vingança voltassem a conviver. Mas se há a satisfação de poder conviver com aquele que se temia, agora também há o receio da vingança, pois o convívio aproxima os inimigos. Essa interpretação em si não está totalmente equivocada. No entanto, minha argumentação tem se desenvolvido em outro sentido. Em meu ponto de vista, a vingança apurinã não é a sobra de um passado guerreiro. Ela é um instrumento social que impede o aparecimento da exploração do ser humano pelo ser humano. Situação que foi exponencialmente ampliada no pós-contato justamente porque nessa nova situação a exploração era a base mesma da sociedade. Assim o que Schiel (1999: 111) vai chamar de "circuito de vingança" parece ser, na verdade, a resistência apurinã ao poder coercitivo.

Portanto, em minha descrição, ao instituir a vingança, Tsura se transforma no arquétipo seguido pelos Apurinã. Utilizo preferencialmente esse conceito aqui no lugar 
de ethos e habitus devido à sua conotação religiosa. Faço uso desse conceito a partir do trabalho de Carl Gustav Jung (2002). Para Jung, arquétipo é uma categoria que explicaria as projeções coletivas da sociedade; por isso ele o vincula ao inconsciente coletivo. Nas diferentes áreas do conhecimento, esse conceito seria expresso como: motivo, temas, representação coletiva, categorias da imaginação, pensamentos elementares ou primordiais (JUNG, 2002: 53). Podendo ser vinculado às forças sugestivas e emocionais das ideias religiosas, Jung (2002: 67s, 74) aproxima esse termo do conceito empírico de anima (alma), como aquilo que anima e põe em movimento o ser social. Estruturados nas projeções sociais, dentre as quais se destacam as dos pares opostos presentes nos motivos mitológicos (JUNG, 2002: 71s, 81), o arquétipo é aquela forma por trás das ideias que institui comportamentos e ações. São as tendências estruturantes presentes no inconsciente coletivo. Os arquétipos estariam, assim, estruturados nas projeções mitológicas e religiosas que a sociedade compartilha e vive no cotidiano ou, como diz Jung (2002: 132), “a sugestão da comunidade produz a identificação com o deus”. No caso em questão, o herói mítico. Dessa forma, o compartilhamento coletivo das histórias míticas introjetaria nos indivíduos o ideal social presente nos arquétipos. Portanto, como uma espécie de sinônimo para ethos e habitus, entendo arquétipo como uma estrutura de projeção de opostos estruturada e estruturante (BOURDIEU, 1992: 191) que põe a sociedade em movimento e assim reproduz a estrutura social.

Como arquétipo da vingança, do desafiador, Tsura institui uma estrutura da vingança. As relações entre aldeias diferentes e, às vezes dentro da mesma aldeia, são permeadas por rixas e vinganças que são atualizações míticas da vingança primordial a qual impede a divisão do corpo social entre aqueles que mandam e aqueles que obedecem. Na prática, os Apurinã vivem cotidianamente essa tradição iniciada arquetipicamente por Tsura ou, dito de outra forma, reinterpretam o seu cotidiano a partir da figura desse herói mítico criador. A vingança aqui é pura retribuição. O sistema de reciprocidade que instaura obrigações mútuas de dar, receber e retribuir (MAUSS, 2015 [1925]: 241ss) também pode ser observado entre os Apurinã. Nesse sentido, os missionários igualmente entraram nessa mesma lógica, embora não a entendessem ou fingissem não a entender. Em dezembro de 1881, Duke vai escrever:

A propósito, eu devo mencionar que os índios de uma grande maloca nas margens do Seruini se tornaram tão enfurecidos porque nós não demos a eles presentes sem eles darem alguma coisa em retorno, que quando nós pedimos que eles soltassem as amarras do Pioneiro [nome da lancha a vapor], em vez de fazer isso eles nos puseram à deriva, e então nos disseram adeus com gritos e lamentos nada agradáveis de ouvir. (SAMM, 1882: 87s) 
Mas diferente de Marcel Mauss (2015 [1925]: 200), para quem a guerra parece ser a quebra da reciprocidade, entre os Apurinã, a potencialidade da guerra é a continuação de uma relação reciprocitária. Só que, "enquanto na troca de bens aquele que dá quer receber, na vingança, o desejo se inverte, e o matador não quer ser pago, nem está obrigado a receber o pagamento" (FAUSTO, 1999: 263s). No entanto, o que estou chamando de estrutura da vingança não se resume na morte do "inimigo". Entre a simples injúria e a pena capital, há um leque de possibilidades. Assim, a retribuição é aqui ato de vingança que é mais bem evidenciada na estruturação de ritos e celebrações nos quais os conflitos são mitigados; às vezes, com violência. Nesses rituais, a "vingança" é uma forma de fabricação de parentesco, de "predação familiarizante" (FAUSTO, 1999: 265ss; VILAÇA, 2006: 187s, 192-205). Michael Heckenberger (2002: 115) vai afirmar que entre os Aruak a predação não parece ser um distintivo cultural. E isso seria inclusive a justificativa que apontaria os Apurinã como diferentes dos demais Aruak. No entanto, logo a seguir Heckenberger descreve uma série de rituais para a redução de conflitos, incluindo antagonismo sexual, eventos esportivos e conflitos ritualizados. Entre os Apurinã, os missionários também registraram rituais semelhantes, como lutas e conflitos encenados ou ritualizados (SAMM, 1876: 87-89); e isso é predação familiarizante. O modo de ser Apurinã parece, dessa forma, semelhante ao modo de ser Wari' descrito por Aparecida Vilaça. Como para os Wari', para os Apurinã, "o processo de diferenciação interna, de 'estrangeirização', é parte do processo de 'inimização'” (VILAÇA, 2006: 61), pois o parente é aquele que se deixa submeter às diversas situações, mesmo de violência ou vexação, e mesmo assim demonstra confiança e entrega aos cuidados do anfitrião. Mas ao contrário dos Wari', para quem os inimigos seriam todos os não-Wari' (VILAÇA, 2006: 56), para os Apurinã, os “inimigos ideais" (FAUSTO, 2001), se essa pode ser uma expressão utilizável, são outros Apurinã. Isso também é o que nos indicam as fontes históricas. William Chandless (1866: 96) ${ }^{4}$, por exemplo, afirmou que os Apurinã praticariam a guerra em especial contra sua própria gente. Assim, enquanto aqueles tidos como iguais sofrem pressão interna para evitar a diferenciação, os ĩparãnyry, como uma categoria de outsiders, parecem representar aqueles que estão em posição de serem apuranizados. Esse parece ser o caso dos Kuwarinyry que, como argumentei (LINK, 2016: 199s), embora sendo um grupo apurinã, sofre pressão social dos demais grupos. No

\footnotetext{
${ }^{4}$ Geógrafo inglês que realizou viagens exploratória no Amazonas na década de 1860, mapeando os rios, descrevendo a geografia, a fauna, a flora e os habitantes. Em 1866, fez uma viagem exploratória ao Rio Purus e ao Rio Acre.
} 
mesmo sentido, também estariam os Manchineri que, embora seja o grupo linguisticamente mais próximos dos Apurinã, viviam, segundo a descrição das fontes (CHANDLESS, 1866: 101), em situação de conflito com os Apurinã. Ora, o conflito aqui indica justamente uma relação de afinidade. Os Kaxarari, ao contrário, mesmo pertencendo a outra família linguística, parecem ser tratados com maior cuidado. Eles seriam os estrangeiros e, portanto, em processo potencial de apurinização. O que estou defendendo aqui é que a "endo-guerra" observada entre os Apurinã e os Manchineri tida como uma expressão do contato com outros grupos não-Aruak, com os Pano no caso dos Manchineri (SANTOS-GRANERO, 2002: 32) - é, na verdade, expressão da dinâmica interna para impedir que o poder coercitivo surja internamente. Nesse sentido, em determinado momento os Apurinã e os Manchineri se separaram porque um grupo ou uma liderança pode ter iniciado um processo de transformação de seu prestígio em poder coercitivo ou primazia sobre o outro grupo. A guerra ou a vingança, nesse sentido, poderia ter sido uma forma de resolver os problemas, mas como os grupos foram se distanciando geograficamente eles acabaram se separando.

Se as fontes descrevem os Apurinã como belicosos e dados a contendas, se a violência é uma dinâmica da sociedade Apurinã, o mesmo não se pode dizer da figura da liderança. A liderança deve atuar como um apaziguador e não como um incentivador de conflitos. O líder Apurinã não é um guerreiro bem-sucedido; ao contrário, parece ser antes um pacificador respeitado. O exercício da chefia é incompatível com o conflito, pois ao posicionar-se de um lado de uma contenda, a liderança política perde o respeito dos demais e seu poder é esvaziado. O conflito parece assim estar do lado de outra figura importante para as comunidades indígenas, o guerreiro. No entanto, é óbvio que, em situações extremas, a liderança é obrigada a tomar partido sob pena de perder completamente sua autoridade.

Como tenho expressado, os Apurinã nos dizem que entre eles todos são chefes. Mesmo afirmado a universalidade da chefia, na prática, os Apurinã também sabem que a liderança é o exercício de poucos. O mesmo não se pode dizer dos guerreiros. A potencialidade guerreira - como aspiração de qualquer indivíduo - pode ser fonte inesgotável de prestígio social (CLASTRES, 2014: 270s); e, por isso, é o lócus natural de todo aquele que busca destaque dentro do grupo. Às lideranças políticas, cabe a tarefa da apaziguação. Aos demais, cabe a tarefa da contestação, da contenda, da desobediência, da oposição. Essa oposição é justamente o que estou chamando de potencialidade guerreira dos Apurinã. Isso não quer dizer que sejam guerreiros de fato, pois para que 
possa existir o guerreiro deve existir a guerra e, como vimos, esta aparece mais como possibilidade do que como evento histórico. Talvez, quando os Apurinã se refiram ao fato de que todos são chefes, eles também tenham a intenção de dizer que todos são guerreiros, que todos são contestadores. Dito de outro modo, que eles não se submetem ao controle de outrem. Dessa forma, o guerreiro apurinã é o vingador por excelência, ou seja, é aquele que administra o antídoto - a vingança - contra a divisão do corpo social entre dominantes e dominados. O guerreiro é, dessa forma, um instrumento pelo qual a sociedade apurinã parece evitar o surgimento de um poder centralizador. Quiçá por causa disso os Apurinã sejam descritos insistentemente como guerreiros, pois as narrativas de contato parecem estar fazendo referência, em realidade, ao fato de que os Apurinã não se submetem ao mando e à exploração.

Clastres vai identificar na lógica guerreira o potencial para impor-se sobre a comunidade indivisa. "A guerra traz dentro dela, portanto, o perigo da divisão do corpo social homogêneo da sociedade primitiva" (CLASTRES, 2014: 280). A confraria dos guerreiros teria, dessa forma, o potencial para usurpar o poder da comunidade. No entanto, como fonte de todo prestígio, glória e poder, a comunidade indígena seria ela própria também o antídoto para que os guerreiros não instituam a divisão entre dominantes e dominados. Esse antídoto, por um lado, está na própria lógica do prestígio concedido que é individual e impediria "ao conjunto dos guerreiros aparecer como coletividade homogênea" em disputa com a comunidade (CLASTRES, 2014: 281). Por outro lado, como a vontade da comunidade é de que a liderança política seja um apaziguador, pois ela não quer viver em constante conflito, a natureza do prestígio guerreiro não parece provir então da mesma fonte do prestígio da liderança política. A necessidade da liderança parece surgir justamente porque a comunidade necessita de um apaziguador. Só existe a liderança política porque a comunidade tem a necessidade de manter-se una em meio à realidade conflituosa. Então, a sociedade apurinã parece ser contra a guerra. Por causa disso, um guerreiro tem dificuldade de se estabelecer como liderança política, pois seu prestígio advém de fonte diferente. O prestígio pode ser obtido também agenciando a violência em tempos de guerra e conflito, mas é um poder efêmero, pois, passado o tempo do conflito, o agenciador perde sua fonte legitimatória. Para o guerreiro, portanto, é necessário viver em constante guerra (CLASTRES, 2014: 278, 281). Assim, uma liderança política pode desempenhar o papel de guerreiro e um guerreiro pode chegar a ser uma liderança política, mas a função da liderança política não está na mesma ordem do papel desempenhado pelo guerreiro. Para um guerreiro se tornar 
uma liderança política, ele deve, em primeiro lugar, renunciar à função básica que lhe concede prestígio que é o conflito, a guerra. Desse modo, ele deve se converter em um pacifista, pois, como disse, a função básica da liderança política é ser um mediador dos interesses da comunidade. Ele deve ser o ponto intermediário que mantêm unido todo o tecido social apaziguando os conflitos. No entanto, como o resto da comunidade se comporta como guerreiros em potencial, a posição do chefe está sempre ameaçada e ele, assim como os guerreiros, não consegue transformar seu "poder" em poder de mando.

Entre os Apurinã, existe um ritual que tipifica sobremaneira a função da liderança política e a função dos guerreiros, pois os colocam lado a lado em oposição a outro grupo de guerreiros. Toda festa tradicional apurinã inicia formalmente com uma "encenação" conhecida localmente como "cortar sanguiré" (SCHIEL, 2004: 81). Trata-se de um diálogo entre duas lideranças acompanhadas de seus guerreiros em armas. A expressão regional vem da própria língua apurinã, para a qual sãkyry significa o ato de falar, de conversar. Mas nesse ritual não se trata de uma conversa cordial. Trata-se de um momento tenso no qual a violência encenada pode se tornar realidade a qualquer momento. $\mathrm{O}$ grupo de guerreiros visitantes aproxima-se como se viessem para a guerra. Os anfitriões, então, vão ao encontro deles. Esse encontro ocorre fora da aldeia. Armas apontadas, ânimos exaltados, os guerreiros prontos para iniciarem a batalha. Neste momento, intervém a figura da liderança política. Situado naquele instante como um guerreiro, ele também troca insultos com seus adversários e está pronto para a batalha, mas, como representante político de sua comunidade, eles iniciam um diálogo no qual vão se reconhecendo como parentes. A tensão dá lugar então a um reconhecimento mútuo. As lideranças apaziguaram o conflito e, em seu lugar, reataram alianças (SCHIEL, 1999: 110). Os convidados, então, baixam as armas e se submetem aos "cuidados dos anfitriões". Eles são alimentados e festejam enquanto a festa durar. Eles se submetem em uma clara demonstração de confiança. É também nesse sentido que Aparecida Vilaça (2006: 107139) demonstra como as festas Wari' são pensadas e performadas como uma forma de perpetuação ou constante fabricação do Outro (do estrangeiro) em um afim. As festas têm como objetivo a predação familiarizante do outro, nas quais "os convidados se constituem em presas dos anfitriões" (VILAÇA, 2006: 129). Assim os Wari’ evitam que seus aliados se tornem inimigos. Ao se submeterem, os convidados reafirmam a confiança naqueles que os recebem, pois aqueles poderiam ser mortos a qualquer instante. Ao mesmo tempo, aqueles que recebem também reconhecem que os convidados não são inimigos, pois se submetem à vexação e à violência predatória. 
Resumindo, a sociedade apurinã é uma sociedade igualitária cujo ethos impede o aparecimento da diferenciação social em termos de exercício do poder de uns sobre os outros. Digo em termos de exercício do poder, porque, a sociedade apurinã não difere das demais sociedades indígenas no que diz respeito à construção de subjetividades. Ela é, em certo sentido, um organismo construtor de sujeitos para estarem a serviço da comunidade. Hierarquias familiares, guerreiros, lideranças e xamãs são constantemente produzidos com o objetivo de estarem a serviço da coletividade. No entanto, o ethos da sociedade apurinã também impede que essas mesmas subjetividades se imponham sobre o desejo comum da comunidade de se manter igualitária. Nessa sociedade igualitária, a fragmentação do poder político é tornada realidade através do arquétipo da vingança. Desse modo, nas sociedades indígenas, a luta social interna (vingança) pode ser tomada, grosso modo, como luta de classe; enquanto que a exo-guerra é interesse estratégico das lideranças guerreiras (obtenção de prestígio ou bens desejáveis). No entanto, se entre os Aruak pré-andinos, os conflitos internos - interesses pessoais - eram obliterados em função das ameaças externas - interesses coletivos (REMARD-CASEVITZ, 2002: 131) -, no caso dos Apurinã não houve tal unidade. No período pós-contato, o sistema de exploração da borracha e demais produtos extrativos engajou diferentes lideranças e aldeias em um sistema de competição interna que potencializou os conflitos tradicionais. Em outras palavras, a presença dos colonizadores não foi tomada como uma ameaça que pudesse pôr em risco a existência dos Apurinã. Ao contrário, eles eram desejados e inclusive aliciados nos próprios conflitos internos dos Apurinã.

\section{Controlando religiosos}

\section{O isolamento dos xamãs como estratégia de controle social}

Como abordei acima, para Clastres, o lócus mais propenso para que a comunidade indígena perda sua "luta" contra o aparecimento da divisão social que institui a exploração de um pequeno grupo sobre o grosso do tecido social é a instituição da guerra. Em sua teoria, um grupo de guerreiros em busca de prestígio poderia conduzir a comunidade para uma situação de "guerra efetiva permanente", o que, em um segundo passo, poderia levar à tomada do poder, ou seja, à instituição dos guerreiros como lideranças políticas instaurando a divisão entre dominantes e dominados (CLASTRES, 2014: 279s). No entanto, se minhas interpretações estiverem certas, para os Apurinã, a guerra - ou no caso 
a potencialidade guerreira - não parece ser a fonte originária de suas preocupações. Aliás, como defendi acima, os Apurinã parecem bem-sucedidos no controle social tanto de seus guerreiros quanto de suas lideranças políticas, de modo que eles não parecem apresentar ameaças ao sistema igualitário. Tanto guerreiros quanto lideranças políticas são, de fato, desprovidos de poder efetivo. Só conseguem fazer em nome da comunidade aquilo que a comunidade quer que façam. Mas existe outro campo no qual a sociedade apurinã parece depositar toda sua preocupação e cuidado, o campo religioso.

Neste ponto, além de Clastres, minha pesquisa é devedora da análise de Hélène Clastres (1978: 55) quando ela afirma a descontinuidade entre o profetismo tupi e o exercício do poder político. Para ela, a confluência dos fenômenos religioso e político em uma mesma liderança é exceção proveniente das vicissitudes do pós-contato que enfraqueceram o controle social sobre as lideranças e possibilitou o surgimento do poder coercitivo. Nesse mesmo sentido, minha abordagem também é devedora do trabalho de Marcel Gauchet "A dívida do sentido e as raízes do Estado". Segundo Gauchet (1980: 51s), a ruptura entre a sociedade igualitária e a sociedade de classes - o aparecimento do Estado - seria proveniente da religião. Depositando o sentido de sua existência fora de si mesma (na religião), a sociedade operaria a primeira ruptura necessária para a segunda ruptura quando as pessoas que representariam as divindades passaram a exercer poder sobre os demais em nome dessas divindades. $\mathrm{O}$ argumento do autor é que para existir enquanto sociedade - para se pensar a si mesma -, a sociedade deve projetar para fora dela mesma o sentido de sua existência. Esse seria o "imperativo radical" que se transforma num paradoxo social, pois, se as pessoas aceitam a heteronomia no fenômeno religioso, também poderiam passar a aceitar no fenômeno político (GAUCHET, 1980: 66-76). A questão está, então, em como as sociedades controlam suas forças religiosas para impedir que apareça a exploração do ser humano sobre o ser humano. Assim o autor conclui: "a história humana não é outra coisa mais do que uma luta longamente vitoriosa contra a alienação política, quer dizer, contra a separação de uma instância de poder, depois a de uma derrota que não terá deixado de se aprofundar (...)" (GAUCHET, 1980: 87).

Assim como todo Apurinã é em potência uma liderança e um guerreiro, todo Apurinã também é em potência um mẽety (xamã). No entanto, ao contrário da liderança e ao contrário dos guerreiros que podem ser encontrados em maior número, poucos chegam a serem reconhecidos como mẽety. A liderança política adquire seu prestígio por ser um bom orador, por ser generoso e por ser um apaziguador. O guerreiro consegue seu 
prestigio através das façanhas obtidas na guerra - tanto na guerra efetiva contra outros grupos quanto na demonstração de sua potencialidade guerreira dentro do grupo (demonstrações públicas, jogos, rituais, brigas). Já no campo religioso, o mẽety recebe seu prestígio decorrente de sua capacidade xamânica que é uma qualidade transcendental. Todos os três adquirem prestígio, em última instância, da capacidade de agenciar a vontade da comunidade. No entanto, enquanto a liderança política e os guerreiros estão no nível da imanência, o xamã opera no nível da transcendência. O mẽety é quem, na comunidade apurinã, vai controlar o sagrado que causa ao mesmo tempo atração e terror; o "numinoso" e o "mistério tremendo" (OTTO, 2007: 37s, 44s). A comunidade tolera a figura do xamã porque ele pode protegê-la dessas forças transcendentais expressas pela predação dos espíritos da natureza e pelos ataques dos xamãs de outras comunidades. Assim, a qualidade xamânica parece ser desejada, mas também temida pelos demais, pois ela é controlável apenas por especialistas. Desse modo, todo Apurinã em sã consciência teme afrontar um mẽety.

Mas o que acontece se o xamã utiliza seu poder xamânico para conseguir poder político? O poder religioso pode se transformar em poder político e assim dividir a comunidade entre dominados e dominadores? Minha hipótese é que, das três formas de lideranças - política, guerreira e religiosa -, a liderança religiosa é quem teria maiores chances de transformar seu prestígio em poder coercitivo. Isso porque a sociedade apurinã parece temer sobremaneira o poder religioso e, como veremos, se esmera para controlálo e subordiná-lo. O que procuro responder a seguir é como a comunidade apurinã impede que seus mẽety se transformem em déspotas exploradores do trabalho alheio?

Os Apurinã concebem um mundo no qual não há distinção de cultura entre seres humanos e animais. Para acessar e entrar em contato com os outros seres, é, pois, necessário alterar o corpo, ou seja, ser capaz de assumir o ponto de vista do Outro. Seria apenas uma questão de moldar o corpo. Para a cosmovisão apurinã, portanto, é possível assumir o ponto de vista dos animais e, poder-se-ia dizer também, de outros povos, inclusive do karywa. Os Apurinã demonstram assim estarem aptos para lidarem com os diferentes tipos de identidades que podem acionar no momento em que necessitam. No entanto, quando se trata dos outros seres ou das terras míticas (Kairiku e do Iputuxity), é o mẽety quem transita, por excelência, entre os "mundos". Embora todos os Apurinã estejam sujeitos às mesmas contingências, no que tange ao transcendente, o pajé difere dos demais em grau, pois ele recebe uma preparação especial que o qualifica para o exercício da pajelança. É ele quem detém as habilidades e o conhecimento necessários 
para lidar com os "flechadores" (kipyatitirã) ou os chefes dos bichos (hãwity) e com as almas (kumuru), ou seja, com os encantes, com as outras perspectivas (VIVEIROS DE CASTRO, 2011: 357). Portanto, é ele quem vai ser procurado pela comunidade em caso de enfermidades. Sobre a atuação dos xamãs, o missionário Clough escreve em novembro de 1875:

Teruã não tem pajé ou curandeiro, mas um que reside perto da boca do Pauini possui considerável influência sobre as hordas vizinhas. Meu anfitrião [Sr. Pinheiros] contou-me que há poucos meses atrás um aprendiz dessa faculdade foi convocado para curar um aldeão doente que estava confinado à sua rede por muitas semanas. Sentado no chão com seus artigos de fetiche [provavelmente um chocalho emplumado], ele fez investigações necessárias, cheirou todo seu paciente e depois se retirou sozinho para a floresta. No dia seguinte ele retornou e, na presença de um grupo de homens pintados e emplumados organizados em um círculo, começou as operações. Novamente cheirando como antes, farejando com toda sua força, ele descansou um tempo com a cabeça sobre os joelhos como se estivesse em profunda contemplação, de vez em quando levantando seu fetiche e passando ele em seus ouvidos e olhos, então repentinamente saltanto de pé ele beliscou a pele do sofredor e virorozamente sugou com a boca vários pontos. Para o assombro dos espectadores ele cuspiu vários grandes ossos de peixe declaradamente extraídos da pessoa que ele declarou ter sido enfeitiçada e, depois de dar instruções quanto ao tipo de alimento a ser administrado, retirou-se; o homem estava bem no dia seguinte e tem permanecido assim desde então. (SAMM, 1876: 115, tradução própria)

Nesse relato de Clough, temos a estrutura de funcionamento da cura xamânica. Após inspecionar seu paciente, o mẽety retira-se para a floresta. Para aqueles que ficaram, ele foi encontrar-se com os encantes e descobrir a causa e o tratamento da doença. No outro dia retorna e, com o auxílio de outros homens da aldeia, realiza a cura sugando de dentro da vítima os ẽtyty (feitiços) que lhe causavam a moléstia. O missionário não diz, mas os etyty só poderiam vir dos encantes ou de outro pajé. Como um ser misterioso ele próprio uma espécie de encante -, o xamã se retira. O pajé é dessa forma tanto desejado pela comunidade pelo bem que pode trazer quanto temido pelo mal que pode realizar. Mas o xamã não é tão diferente dos demais. Na verdade, antes de ser mẽety ele era como qualquer outro apurinã. Ele apenas adquiriu um conhecimento que o distancia da comunidade e o aproxima dos encantes. Assim, embora todos possam ser xamãs em potencial, para se transformar em um pajé, muitos são os obstáculos que nem todos estão dispostos a enfrentar. Para isso, o candidato a pajé tem que passar por um intenso processo de jejum, retiros espirituais e abstinência sexual. Na verdade, o mẽety apurinã é um asceta.

Várias foram as pessoas que me informaram sobre o processo necessário para que um Apurinã seja reconhecido como mẽety e todas repetiram uma fórmula semelhante a esta que Manuel Marcos de Souza Apurinã (Mathiũ) me passou em 24 de maio de 2009. Para se tornar xamã, o candidato a mẽety recebe treinamento de outro xamã e é submetido 
a um rigoroso regime alimentar no qual pode comer apenas certos tipos de alimentos em pequena quantidade. Sua dieta é muito reduzida e completada pela ingestão de katsupary (folha de coca) e de certos tipos de folhas amargas (Mathiũ disse que teria que beber suco da folha de katsinhary) que, junto com o consumo abundante de awyry (rapé), o auxilia a transcender. Para completar seu ciclo de formação, tem que passar uma temporada isolado na mata (îtupa) sob rígidas restrições alimentares. Essa temporada pode durar meses. Nesse retiro, é esperado que receba a visita dos encantados, como o chefe da onça (hãkyty hãwity) e o chefe da sucuri (wainamary hãwity). Ao receber a visita dos encantados, o xamã não os vê como animais, mas como gente, o que significa que ele participa da perspectiva desses seres míticos. A partir desse momento, ele já transita entre os mundos. Mẽety e encantados confraternizam awyry e conhecimentos. Dos chefes dos encantados, o mẽety recebe os étyty (pedras enfeitiçadas) que são a fonte do poder dos pajés. Se ele for corajoso para enfrentar os encantados, ele recebe os étyty como prêmio. Para testar seus novos poderes, o mẽety joga seus étyty nas árvores as quais adoecem e morrem (LINK, 2012: 271s).

O processo de formação do mẽety apurinã não termina com esse retiro. Ele é apenas o ponto de partida de uma vida de "ascese". Notadamente, o tempo de retiro pode variar, mas o reconhecimento de suas habilidades está intrinsecamente relacionado com seu estilo de vida. Por isso, muitos Apurinã afirmam que hoje os mẽety são fraquinhos, pois ninguém quer se submeter a uma vida de sacrifícios. O equivalente é dizer que antigamente eles eram fortes. Embora o xamã apurinã possa casar, a vida de ascese e sacrifícios também implica em uma família pequena. Isso é justificado porque se diz que o pajé tem outra família no mundo dos animais e é por isso que ele passa grande parte do seu tempo lá. Assim, se aquele que se diz mẽety possui uma família numerosa, ele não é reconhecido pelos demais como tal. Isso porque sua vida pública o desqualifica como xamã. Inversamente, se uma pessoa não se considera mẽety, mas tem uma vida que o identifica como um asceta, ele passa a ser reconhecido como tal. Desse modo, geralmente os xamãs apurinã são pessoas mais idosas, viúvos e viúvas, ou uma pessoa menos sociável. Assim, como vemos, o controle social inibe que o pajé tenha família numerosa; condição fundamental para que um Apurinã exerça a liderança política. Portanto, fica evidente que, se o mẽety apurinã lida com poderes sobrenaturais, ele também não possui muitos aliados que poderiam sustentá-lo numa eventual tentativa de tomada do poder político. É, consequentemente, desta forma que a sociedade apurinã delimita o poder de atuação do xamã: legitimando e controlando a fonte de poder e conhecimento xamânica. 
Para os Apurinã, portanto, religião e política parecem não se misturarem. A política seria a arte de se relacionar no imanente: com a comunidade local, com os aliados e com os inimigos; a religião, por sua vez, seria a arte de se relacionar com o transcendente: o sobrenatural. Como fonte de legitimidade, a comunidade apurinã reconhece as habilidades xamânicas pelos distintivos que distanciam e isolam o mẽety do resto do tecido social. Ele é um estranho no corpo social da comunidade. O processo de adquirir conhecimento xamânico é o mesmo processo que distancia o mẽety da comunidade. É um processo de estrangeirização. Só que em vez do xamã ser predado por outra comunidade ou por outro povo ele é predado pelo transcendente. Na verdade, ele não é completamente predado, mas através de sua ascese ele aprende o caminho que o leva até os outros mundos, até os encantados. Dessa forma, é o próprio xamã quem se entrega aos encantes e, por isso, ele também pode voltar com segurança. Mas uma vez que ele regressa desses outros mundos - dessas outras perspectivas -, ele não é mais um aliado totalmente confiável.

É, portanto, controlando a legitimidade do prestígio do mẽety que a sociedade apurinã controla a força religiosa e impede que ela se transforme em força política. A comunidade local, inclusive agencia sua força religiosa - seus mẽety - contra seus inimigos. Mesmo entre as aldeias aliadas, com as quais se mantêm trocas de matrimônio e festas, o ataque de um xamã permanece sempre como uma possibilidade. Desse modo, a comunidade local parece jogar seu mẽety contra as outras comunidades e contra os outros xamãs. A comunidade local parece assim literalmente isolar seu mẽety do convívio social. Fazendo com que seu xamã obtenha legitimidade tornando-se temido pelas outras comunidades, a comunidade local também impossibilita que ele consiga aliar-se com outras comunidades e com outros xamãs. Assim, ao fazer uso político das habilidades de seu xamã, a comunidade apurinã impede que ele faça uso de suas habilidades com finalidade políticas.

Mas o que acontece se um xamã escapa ao controle social e começa a agenciar seu poder religioso para obter poder político? O que acontece se um xamã começa a tirar vantagem de seus poderes coagindo o corpo social? Nesses casos, a comunidade decreta a sentença de morte do mẽety. Como um personagem que vive sob a necessidade constante de mostrar-se correto e eficaz devido à dinâmica das constantes acusações que lhes são imputadas, ele corre o risco constante de recebe as sanções do grupo (SZTUTMAN, 2005: 360). Nesse sentido, entre os diferentes grupos indígenas da Amazônia, abundam histórias de assassinatos coletivos de pajés. Entre os Apurinã, 
também ouvi várias histórias semelhantes. E os missionários anglicanos também registraram a mesma estrutura social.

O dia que Xikama morreu eu vi [Clough] um grupo de índios conversando muito seriamente em voz baixa. Eles pareciam amedrontados, e quando eu perguntei a causa, "a tartaruga chora por Xikama!" foi a resposta. "Xikama foi enfeitiçado pelo pajé de Panyery [Peneri], ou ele nunca teria morrido quando o sol estava alto! Pajé é homem mal! Eu mato pajé. Eu atiro nele na frente, e as flechas atravessam as suas costas! Ele me enfeitiça na próxima vez, e me mata! Ugh!" e ele cuspiu no chão e pisoteou violentamente em cima do ponto com seu pé direito, como se ele tivesse assim esmagado a vida de seu suposto

E o missionário Clough continua: inimigo. (SAMM, 1876: 205, tradução própria)

A profissão de pajé não é completamente desprovida de perigo, pois no último setembro [1875] um curandeiro, chamado Maniuá [Manywa], que vivia no Iguariã [Ĩkawarihã], um afluente do Teuini, onde meu colega [Polak] está justo agora, foi acusado de ter enfeitiçado um índio chamado Capung-gapá [Kapũkapa] e causado sua morte. Para prevenir que ele fizesse mais mal e para encorajar [sic.] o resto de seus irmãos de profissão, ele foi surpreendido e brutalmente morto por um bando de homens, que teriam menos remorso matando ele do que eles teriam em aniquilar uma cobra cascavel. Eles ouviram minhas admoestações e disseram "pajé não mata karywa. Karywa é forte, mata pajé. Curandeiro tem mau espírito. Karywa chegou agora, não conhece nada. Apurinã conhece melhor!" e eu estou persuadido que eles plenamente acreditam que Xikama tenha sido enfeitiçado e morto pelo próprio homem de quem ajuda eles implorariam a primeira vez que eles ficaram seriamente enfermos. (SAMM, 1876: 205)

Assim é mais uma vez a vingança que se insurge contra o poder coercitivo. Só que nesse caso ela é coletiva, pois como disse o processo de formação de um xamã o distancia do corpo social, de modo que termina opondo comunidade e pajé. $\mathrm{O}$ mẽety então é um estranho em quem não se pode confiar totalmente. Naturalmente, essas situações foram exponencialmente multiplicadas no período pós-contato, pois muitos mẽety foram acusados de serem os causadores de epidemias. Desse modo, o período posterior ao contato também se revelaria uma época difícil para se ser um xamã. Assim, presa à estrutura cultural apurinã a profissão xamânica foi vitimada pela conjuntura do contato. Além das acusações de predação interna (feitiços), os mẽety ainda passaram a ser deslegitimados pelos seus concorrentes cristãos, os missionários protestantes e católicos. Dessa forma, hoje em dia, em quase todas as aldeias, os Apurinã vão afirmar que eles não têm mais mẽety. No entanto, ao mesmo tempo em que constatam a falência da instituição da pajelança, no contexto de revitalização da cultura apurinã, os Apurinã instituem, no discurso, a necessidade de formar a juventude para assumir esse papel. Inúmeros são os jovens que se dizem dispostos a se tornarem mẽety, mas não estão dispostos a se submeterem à ascese e aos sacrifícios exigidos. Desse modo, apesar de alguns deles se autoproclamarem mẽety, não são reconhecidos como tal pelas comunidades. 
Ao trabalhar com grupos Aruak, Silvia Vidal (2002: 258) especula que os ancestrais dos Baré e dos Warekena teriam sido afiliados a diferentes confederações multiétnicas flexíveis e essas confederações teriam sido lideradas por xamãs-guerreiros carismáticos através do que ela chama de modelo de liderança “teocrático genealógico". Na segunda metade do século XVIII, o contato com as sociedades coloniais europeias, com os Caribe e com os Tucano levou os Baré e os Warekena a outro modelo, o “comercial-militar". Esse novo modelo se baseia na subjugação militar e na conversão dos parceiros comerciais em apoiadores políticos e aliados militares. Na hipótese de Vidal, podemos notar então que a transição para um poder mais coercitivo teria sido realizada durante o período colonial. Teoria que também pode ser aplicada aos Apurinã para o final do período imperial, pois, nesse período, os Apurinã foram incorporados ao sistema extrativista e novas relações de trabalho foram se impondo. No entanto, seu modelo de liderança teocrática - xamãs-guerreiros - do período anterior ao contato não pode ser aplicado para os Apurinã. Pois, para os Apurinã, o que parece uma constante é justamente a estrutura social que impede que um mẽety consiga usurpar o poder de mando. O período pós-contato gerou desconfianças para com as lideranças políticas o que ampliou os conflitos e as vinganças que são justamente expressões da evitação da exploração. O mesmo ocorreu com as lideranças religiosas que foram acusadas de agenciarem seus poderes em benefício próprio.

Em uma oficina de revitalização da língua apurinã que coordenei na aldeia Mipyry, na Terra Indígena Água Preta/Inari, durante duas semanas em fevereiro de 2010, além das curas xamânicas que eram expressões da mestiçagem cultural, pude observar a estrutura xamânica em ação. Ao contrário daquelas sessões pequenas nas quais são articuladas as relações de parentescos e amizades mais próximas, a presença de várias pessoas que se auto-afirmavam como mẽety trouxe um desconforto para os demais participantes e, sobretudo, para os anfitriões. Esse desconforto, ao contrário das sessões comunitárias, propicia um olhar mais direto sobre a estrutura xamânica apurinã em ação. A presença dessas pessoas que se diziam mẽety, mas que pertenciam a aldeias e famílias diferentes, aflorou conflitos internos presentes na memória. Isso se refletia, por exemplo, no fato das pessoas expressarem que estavam vendo vultos e que estavam com medo de que algo acontecesse. Diziam que "muitas forças" estavam agindo na aldeia. Mas um episódio em particular que presenciei traz à tona toda a discussão sobre a natureza do poder dos xamãs. Ao final da tarde, depois de encerrado o estudo formal em sala de aula, estava sentado junto a um pequeno círculo de pessoas na casa da liderança da aldeia 
confraternizando awyry. Um jovem mẽety que participava da oficina adentrou a sala, sentou-se e pediu para tomar awyry. O pajé, em sinal de respeito, ofereceu o rapé em sua mão e emprestou sua mexikana (inalador de rapé). O inalador do mẽety é um instrumento dotado de poderes mágicos com o qual ele cura ou provoca enfermidades e não costuma ser emprestado se não há uma relação de confiança. No entanto, em clara demonstração de desconfiança, o jovem mẽety espalhou bem o rapé na mão de seu homólogo como se estivesse procurando por étyty (pedrinhas de feitiço). Depois de inalado tudo, ainda em clara demonstração de desafio, soprou a mexikana. O velho mẽety não gostou do que sucedeu e repreendeu o jovem. O que ocorre é que, como uma sarabatana, a mexikana serve para atirar os ẽtyty dos xamãs. Perdi esta parte, mas provavelmente o velho xamã deve ter feito alguma coisa para neutralizar o étyty do desafiante. Mas o que interessa é que, desafiando o pajé do lugar ao jogar um feitiço com sua própria mexikana, o jovem demonstra não ter medo e que estava em busca de prestígio. Essa busca de prestígio xamânico também se evidencia no nome que o jovem pajé tinha adotado recentemente. Ele se autoproclamava Tsura. Como vimos, Tsura é o herói mítico criador que é referido atualmente como "Deus Criador" em paralelo com a estrutura teológica cristã. Mas ele também é o arquétipo do desafiador, o arquétipo da vingança. O jovem mẽety, portanto, parece querer agenciar o poder religioso e o poder político. Eis aí o perigo que a sociedade apurinã parece tentar evitar.

\section{$O$ arquétipo do bom pajé como antídoto ao poder coercitivo}

Se a sociedade apurinã impõe limites que impedem concretamente que um mẽety consiga usurpar o poder político da comunidade, ela também desenvolve estratégias que instituem relações desejáveis e elas podem ser mais bem percebidas nas narrativas míticas. Assim, através dessas narrativas, a comunidade ensina ao candidato a mẽety como um bom xamã deveria se comportar. Ela lhe informa o que se espera dele. A principal dessas estratégias é aquela que institui o arquétipo do bom xamã, o qual tenho identificado com a figura mítica de Kanynary. Ao contrário de Tsura que é descrito como uma liderança política, apenas agenciando esporadicamente qualidades xamânicas - pois todos os ancestrais, como superiores aos Apurinã atuais, são representados como usuários de poderes xamânicos -, Kanynary é o mẽety por excelência. Passo agora a descrever e analisar uma versão da história do Kanynary que foi produzida no contexto da mesma oficina de língua apurinã citada acima. Essa história foi publicada ainda naquele ano e a versão que 
segue foi extraída dessa publicação. Outras versões dessa história podem ser encontradas na tese de Schiel (2004: 230-236).

Kanynary era pajé forte. Ele era casado com uma mulher bonita [Eriana, conforme Schiel (2004: 230)]. Os seus primos tinham raiva dele. Eles diziam: vamos matar Kanynary. Ele já sabia disso. Kanynary fez o seu roçado. Quando ele foi queimar o seu roçado, ele foi buscar os seus primos. Eu vim buscar vocês, ele disse! Ei, nós vamos, eles disseram! Eles foram com ele. Lá eles disseram: agora vamos matar Kanynary. Eles foram queimar o roçado dele, arrodearam-no com fogo. Kanynary estava no meio do roçado. Um disse: Kanynary não está mais vivo. O outro disse: é verdade! Dessa forma eles voltaram para a aldeia. Um disse: vou casar com a mulher do Kanynary. Você não vai casar, eu é quem vou casar, o outro disse. Já chegamos à casa do Kanynary, eles disseram. - Você está aqui Kanynary! É você! Ele disse: eu estou aqui! Pode subir! Assim eles disseram: Kanynary ainda está vivo! Então eles foram embora. (LINK, 2010a)

Nesse pequeno fragmento das histórias que narram as aventuras de Kanynary, podemos notar de imediato certa "passividade" do herói xamã. A história inicia com uma afirmação categórica que reconhece a força xamânica dele. No entanto, apesar de toda sua capacidade transcendental, Kanynary não esboça retaliação frente às tentativas de seus primos. Em apurinã, a forma narrativa em si é ritmada e cômica, cativando a atenção e o riso dos ouvintes, mas ela também é cômica porque todos esperariam que o poderoso mẽety desse uma lição em seus primos. No entanto, não é isso o que acontece. Kanynary desvencilha-se das armadilhas que os seus lhe preparam sem causar danos a seus oponentes. Ele nem mesmo esboça qualquer reação que indicasse uma possível vingança no sentido arquetípico de Tsura.

Os informantes de Schiel (2004: 63, 230) lhe indicam que Kanynary seria Miutymãnety, enquanto Tsura seria Xuapurunyry5. Eles também lhe afirmam que Tsura infringia a lei do incesto, enquanto Kanynary permanecia fiel à tradição do grupo. Na narrativa de Kanynary, a palavra empregada em apurinã para primo é epyry que designa os irmãos de clã. Por isso, eles também almejavam tomar a mulher de Kanynary como esposa. Como a esposa dele pertence ao outro clã, eles não estariam infringindo a proibição do incesto. Dessa forma, o mito nos diz que são os parentes mais próximos de Kanynary que o rejeitam e tentam matá-lo. São seus companheiros de clã. Os primos parecem assim representar a comunidade local em oposição ao seu xamã. Numa relação pautada pela retaliação, esperar-se-ia que Kanynary empreendesse sua vingança. No entanto, ao contrário de qualquer expectativa, ele é apresentado quebrando o arquétipo

\footnotetext{
${ }^{5} \mathrm{O}$ povo Apurinã divide-se em dois troncos/clãs exogâmicos patrilineares: Xuapurinyry e Miutymãnety. O casamento correto ocorre entre esses dois clãs. Aqueles que pertencem ao mesmo grupo são chamados de nepyry ou nepyru (meu irmão, minha irmã) e aqueles que pertencem ao outro clã de numinapary ou numinaparu (meu cunhado, minha cunhada).
} 
da vingança de Tsura. Assim, Kanynary é o bom xamã. É aquele que representa o arquétipo para os futuros xamãs. Embora seja poderoso, ele não usurpa o poder para exercer sobre os outros. Mais do que isso, ao quebrar o paradoxo da vingança, Kanynary parece mesmo oferecer a outra face. Se fosse para fazer uma relação com o Cristianismo, diria que Kanynary está mais para Jesus Cristo do que Tsura. Este último pode ser mais bem comparado ao Deus Juiz do Antigo Testamento e à lei do talião, "olho por olho e dente por dente".

\section{Considerações finais}

Como vimos, Pierre Clastres (2012: 215) vai expor a tese de que é a ruptura política e não a mudança econômica, a responsável pelo aparecimento da sociedade de classes e, portanto, da exploração do ser humano sobre o ser humano. Como argumentei, isso parece ser verificável também entre os Apurinã. No entanto, diferente de Clastres para quem o poder coercitivo parece provir mais substancialmente do grupo dos guerreiros, para os Apurinã ele parece provir perigosamente da religião. Clastres chega a assinalar em um breve momento de sua arguição que talvez os karai - os profetas TupiGuarani que exortavam seu povo para buscarem a terra sem mal - pudessem vir a ser os causadores do infortúnio da sociedade igualitária. Diz ele: "no discurso dos profetas jaz talvez em germe o discurso do poder, e sob os traços exaltados do condutor de homens [do karai] que diz o desejo dos homens se dissimula talvez a figura silenciosa do Déspota" (CLASTRES, 2012: 231). No entanto, Clastres se mantém no talvez. Ele não chegou a aprofundar essa questão. Hélène Castres, ao contrário, vai afirmar mais categoricamente a separação entre as forças políticas e as forças religiosas. Para ela, quando um profeta tupi chegava a se tornar chefe, ele deixava de ser completamente profeta. Portanto, Hélène foi mais longe do que Clastres nesse sentido, mas o que a tese de Pierre Clastres, nos diz sobre as sociedades indígenas - e nisso Hélène Castres também é signatária - é que elas mantêm "o esforço permanente para impedir os chefes de serem chefes" (CLASTRES, 2012: 231). Como procurei argumentar, a essa fala de Clastres, deveríamos incorporar também o empenho dos Apurinã em controlarem as forças perigosas da Religião.

Data de submissão: $13 / 13 / 2020$

Data de aceite: 11/06/2020 


\section{Referências Bibliográficas}

BOURDIEU, Pierre. Economia das trocas simbólicas. $3^{\text {a }}$ ed. São Paulo: Perspectiva, 1992.

BOURDIEU, Pierre. Razões práticas: Sobre a teoria da ação. Campinas: Papirus, 1996.

CHANDLESS, Willian. Ascent of the River Purûs. Journal of the Royal Geographical Society of London. Vol. 36, p. 86-118, 1866.

CLASTRES, Hélène. Terra sem Mal. São Paulo: Editora Brasiliense, 1978.

CLASTRES, Pierre. A sociedade contra o estado - pesquisa de antropologia política. São Paulo: Cosac Naify, 2012 [1974].

CLASTRES, Pierre. Arqueologia da violência: pesquisas de antropologia política. $3^{\mathrm{a}}$ ed. São Paulo: Cosac Naify, 2014 [1978].

EHRENREICH, Paul. Beiträge zur völkerkunde Brasiliens. Belin: Verlag von W. Spemann, 1891.

FAUSTO, Carlos. Da inimizade: formas e simbolismo da guerra indígena. In: NOVAES, Adauto (Org.). A outra margem do ocidente. São Paulo: Companhia das Letras, 1999. p 251-282.

FERNANDES, Florestan. A função social da guerra na sociedade tupinambá. São Paulo: Globo, 2006.

GAUCHET, Marcel. A dívida do sentido e as raízes do Estado: política da religião primitiva. In: Clastres, Pierre; et alli. Guerra, Religião, Poder. Lisboa: Edições 70, 1980. p. 49-89.

HECKENBERGER, Michael J. Rethinking the Arawakan Diaspora: hierarchy, regionality, and the Amazonian formative. In: HILL, Jonathan D.; SANTOS-GRANERO, Fernando (Orgs.). Comparative arawakan histories: rethinking language family and culture area in Amazônia. Illinois: University of Illinois, 2002. p. 99-122.

HILL, Jonathan D.; SANTOS-GRANERO, Fernando. Introduction. In: HILL, Jonathan D.; SANTOS-GRANERO, Fernando (Orgs.). Comparative arawakan histories: rethinking language family and culture area in Amazônia. Illinois: University of Illinois, 2002. p. 1-22.

JUNG, Carl Gustav. Os arquétipos e o inconsciente coletivo. 2 ed. Petrópolis: Vozes, 2002.

LABRE, Antonio Rodrigues Pereira. Rio Purus: Notícias. Maranhão: Tipografia do Paiz Imp. M. F. V. Pires, 1872.

LAZARIN, Marco Antônio. A descida do Rio Purus: uma experiência de contato interétnico. Dissertação de Mestrado. Brasília: UNB, 1981. 
LINK, Rogério Sávio (Org.). Kanynary sãkiry: conto do Kanynary. São Leopoldo: Oikos, 2010.

LINK, Rogério Sávio. Transitando entre os mundos: em busca de uma teologia indígena. In: SCHAPER, Valério Gilherme; et alii (orgs.). Deuses e Ciências na América Latina. São Leopoldo: Oikos, 2012. p. 268-279.

LINK, Rogério Sávio. Vivendo entre mundos: o povo Apurinã e a última fronteira do Estado brasileiro nos séculos XIX e XX. Tese de doutoramento. Porto Alegre: UFRGS, 2016.

MAUSS, Marcel. Ensaio sobre a dádiva: forma e razão da troca nas sociedades arcaicas. São Paulo: Cosac Naify, 2015 [1925].

OTTO, Rudolf. O sagrado: Os aspectos irracionais na noção do divino e sua relação com o racional. São Leopoldo: Sinodal; Petrópolis: Vozes, 2007.

POLAK, Jacob Evert Resyek. A grammar and a vocabulary of the Ipuriná language London: Kegan Paul, Trench, Trübner and Co., 1894.

REMARD-CASEVITZ, France-Marie. Social forms and regressive history: from the Campa cluster to the Mojos and from the Mojos to the Landscaping Terrace-Builders of the Bolivian Savana. In: In: HILL, Jonathan D.; SANTOS-GRANERO, Fernando (Orgs.). Comparative arawakan histories: rethinking language family and culture area in Amazônia. Illinois: University of Illinois, 2002. p. 123-146.

SAMM (South American Missionary Magazine). Anos 1873-1890. Londres.

SANTOS-GRANERO, Fernando. The arawakan matrix: ethos, language, and history in native South America. In: HILL, Jonathan D.; SANTOS-GRANERO, Fernando (Orgs.). Comparative arawakan histories: rethinking language family and culture area in Amazônia. Illinois: University of Illinois, 2002. p. 25-50.

SCHIEL, Juliana. Entre patrões e civilizadores: Os Apurinã e a política indigenista no Médio Rio Purus na primeira metade do século XX. Dissertação de mestrado. Campinas: Unicamp, 1999.

SCHIEL, Juliana. Tronco Velho: Histórias Apurinã. Tese de doutoramento. Campinas: Unicamp, 2004.

SCOTT, James C. The art of not being governed. An anarchist history of upland Southeast Asia. London: Yale University Press, 2009.

SZTUTMAN, Renato. O profeta e o principal: a ação política ameríndia e seus personagens. Tese de doutoramento. São Paulo: USP, 2005.

VIDAL, Silvia M. Secret religious cults and political leadership. In: HILL, Jonathan D.; SANTOS-GRANERO, Fernando (Orgs.). Comparative arawakan histories: rethinking language family and culture area in Amazônia. Illinois: University of Illinois, 2002. p. 248-268. 
VILAÇA, Aparecida. Quem somos nós: Os Wari’ encontram os brancos. Rio de Janeiro: UFRJ, 2006.

VIVEIROS DE CASTRO, Eduardo. Perspectivismo e multinaturalismo na América indígena. In: A inconstância da alma selvagem - e outros ensaios de antropologia. São Paulo: Cosac Naify, 2011. p. 347-399. 